\title{
The Determinants of Consumers' Preference for Value Added Groundnut in Esan West Local Government Area of Edo State
}

\author{
Aina Oluwatunmise Sunday ${ }^{*}$, Muhammed Tukur Bappah, Ibrahim Isiaka, Musa Inuwa Arab, \\ Gadzama Ndacimari Salihu, Hassan Basirat \\ Department of Agricultural Extension and Management, Federal College of Horticulture, Dadin-Kowa, Gombe, Nigeria \\ Email address: \\ ainaosunday@hotmail.com (A. O. Sunday),bappamuhammadtk@gmail.com (M. T. Bappah), isiakaibrahim75@gmail.com (I. Isiaka) \\ ${ }^{*}$ Corresponding author
}

\section{To cite this article:}

Aina Oluwatunmise Sunday, Muhammed TukurBappah, Ibrahim Isiaka, Musa Inuwa Arab, Gadzama Ndacimari Salihu, Hassan Basirat. The Determinants of Consumers' Preference for Value Added Groundnut in Esan West Local Government Area of Edo State .American Journal of Operations Management and Information Systems. Vol. 3, No. 1, 2018, pp. 1-5. doi: 10.11648/j.ajomis.20180301.11

Received: August 23, 2017; Accepted: September 23, 2017; Published: February 24, 2018

\begin{abstract}
As the world is drifting into globalization with attendant competition coupled with rise in income of consumers, providers of goods and services are becoming extremely conscious of what goods and services they produce or render tomeet and satisfy the ever sophisticated and differentiated consumer's needs. The study examined the determinants of consumers' preference for value added groundnut in Esan West Local Government Area of Edo State. The objectives were to determine the socio-economic characteristics of the respondents examine the determinants of consumers' preference for value added groundnut and identify the different form of value addition in groundnut marketing. Multistage sampling technique was employed in data collection, a total of 76 respondents were selected. Descriptive statistics involving tables, frequency, percentage and mean were used for analysis of the data collected. The result indicates that that majority of the respondents were female (69.7\%), between the age of 20-29 years old, had formal education (98.7\%) with household size of less than5 members $(48.7 \%)$. Fried and bottled groundnut $($ mean=3.28), fried and peeled groundnut (mean=2.92) and boiled groundnut (mean=2.83) were frequently consumed by the respondents. Important factors influence groundnut preferred were taste (mean=2.91), ability to store for long (mean=2.53), price $(m e a n=2.30)$ and quality $(m e a n=2.24)$. The major constraints associated with consumers' preference for value added groundnut were found to be; inadequate capital, lack of storage facilities, and health issues. It was recommended that modern storage facilities be provided for groundnut marketers and groundnut should be fortified with vitamins to encourage increased patronage.
\end{abstract}

Keywords: Determinants, Consumers, Preference, Value, Groundnut

\section{Introduction}

Groundnut (Arachis hypogaea) is one of the chief sources of vegetable oils extremely used for cooking purposes around the World as well as in Nigeria. Depending on the variety, the high oil (37.42 to $55.69 \%$ ) and protein (18.93 to $30.22 \%)$ content makes it an important food and oil seed crop [1]. Ahypogaea is grown on about 24.6 million hectares of land of land in tropical regions and warmer area of temperate regions of the world, with an annual global production of about 38.2 million tons [2]. The nuts are crushed to remove the kernels that provided ingestible protein, cooking oil, a significant source of animal feed and important raw materials for many industrial products. Peanut kernels are eaten fresh or roasted, used in cookery, confectionaries and about $47 \%$ of the produce is crushed for edible oil [3]. The groundnut seeds are particularly valued for its [protein content, which is well balanced and thus constitute a nutritious food for growing, children and pregnant women [4]. Groundnut oil is high in energy, has very good lipid profile with saturated, mono-unsaturated and poly-unsaturated fats in health proportion reverted a polyphenol antioxidant which has been found to have protective function against cancer, heart disease and viral infection [5]. The production of groundnut 
oil and its products (raw and fried) is an important source of income for women in African countries [6]. Oil cake and plant residue have varied uses like cattle feed, soil amendments, manures and pest control. Groundnut is directly consumed as raw nuts or in processed form developed through different chains.

[7] pointed that the value chain in any crop includes arrange of activities that are required to bring crop a crop product from its conception, sources raw materials and intermediate inputs, its marketing and distribution to final consumer. [8] Stated that the value chain is incorporated production, transportation, processing, marketing and consumption of a given product or services. Value chain analysis helps in understanding and evaluating the value addition, income distribution and other benefit like employment generation.

In Nigeria, groundnut (Arachis hypogaea) is the most popularly consumed plant food that is oil seeds [2]. In Ghana and Nigeria boiled groundnuts are eaten as street food. Groundnut are processed and prepared indifferent ways by virtually all ethnic groups in Nigeria and forms part of many Nigeria traditional food products, diet and snacks. In Nigeria groundnut is primarily consumed as roasted or boiled whole nuts or processed to extract the oil. In the Eastern part of Nigeria, groundnuts are made into a local peanut butter called "oseorji" and eaten with garden egg. In Northern Nigeria, groundnut is popularly made into snack called "kulikuli" which is a defatted fried cake after oil has been extracted from the groundnut. Groundnuts have many uses. It can be eaten raw, used as recipes, made into solvents and oils, medicines, textile materials and peanut butter, as well as many other uses. Popular confections made from groundnut include salted groundnut, groundnut butter (sand winches), peanut, candy bars, peanut bottle and shelled nuts (plain or roasted). Salted groundnut are usually roasted with oil and packed in retail sizes, plastics bags or hermetically sealed cans. Dry roasted salted groundnuts area lsomarketed in significant quantities. Groundnut is often a major ingredient in mixed nuts because of their relative cost compared to Brazil nuts, cashew nuts and walnuts. The per capital consumption of groundnut by children and women on a daily basis is 37 and $65 \mathrm{~kg}$ respectively [9].

The rising prices of "dry fruits" also have paved way for the cheaper table nut as a preferred option among the urban middle class; hence there is an increased demand across the spectrum of population for these groundnut products [10]. The individual consumers have a set of preference and value whose determinations are outside the realm of economics. They are no doubt dependent upon culture, education and individual taste, among a plethora of other factors. If individual purchases a particular good, then the opportunity cost of the purchase is the forgone goods the consumer could have bought instead. Consumers buying decision is very complex. Usually purchasing intention is related to consumer's behavior, perception and their attitude. Purchase behavior is an important key point for consumers during considering and evaluating of certain product [11]. Stimuli is received and processed by the consumer in conjunction with memories of previous experiences and external variables in the form of either environmental influences or individual differences. The environmental influence identified include: culture, social class, personal influence, family and situations while the individual influence include consumer resources, motivation and involvement, knowledge, attitude, personality, values and lifestyle [12]. Research shows that extrinsic cues play an important role in influencing consumers purchase intention than intrinsic cues [13]. This call for the analysis of the determinants of consumer's preference for value added groundnut in Esan West local government area of Edo state. Thus the objective of the study is to examine the socioeconomic characteristics of the respondents, examine the determinants of consumer's preference for value added groundnut and to identify the different forms of value addition in groundnut marketing.

\section{Methodology}

\subsection{Study Area}

The study was carried out in Esan West local government Area of Edo State, South-South geo-political Zone of Nigeria. Esan West is one of the eighteen (18) local government areas in Edo State Nigeria with its headquarters in Ekpoma. It has an area of $502 \mathrm{~km}$ and a population of 125,842 people based on the professional figures of the National Population Commission [14] and the local government was created in 1991. The major towns and communities in Esan West Local Government Area include: Ekpoma, Iruepken, ogwa, Urohi, Emuhio, Egoro, Ihumudumu, Ujemen, Okhum, Igor, Uhiele, Illeh.

The economic activities in the area are schools (primary, secondary and tertiary), furniture making, commerce and they are not limited to banking, retail, trading of consumables and farming. The major Agricultural products in the areas are rice, cassava, cocoyam and pineapple. The indigenes of the local government are predominantly subsistence farmers with small farm holdings and the area is predominantly of Esan speaking language but also comprises of people from other tribes such as the Hausa, Yoruba, Delta and Igbos.

\subsection{Sampling Procedure}

Multistage sampling technique was employed in data collection, since the sampling was done in three stages, Esan West Local Government Area of Edo State consist of ten (10) wards. The first stage was the random selection of four (4) wards out of ten (10) wards in the study area. The second stage was the purposive selection of two (2) communities from each of the four (4) wards selected. The third stage was the random selection of ten (10) consumers of groundnut to give a sample size of eighty (80) respondents. However only seventy six (76) of the administered instrument was found useful for analysis; the others were improperly filled. 


\subsection{Data Collection Instrument}

The data gathering instrument for this study was the questionnaire and interview schedule. The questionnaire was administered on literate respites while the interview was used for those who could not read or write

\subsection{Data Analysis Technique}

Simple descriptive statistics comprising frequency distribution, percentage, mean and likert scale was used in data analysis.

\section{Results}

Table 1. The Socio-economic Characteristics of the Respondents.

\begin{tabular}{lll}
\hline Variable & Frequency & Percentage \\
\hline Age Group (year) & & \\
Less than 20 & 8 & 10.5 \\
$20-29$ & 51 & 67.1 \\
$30-39$ & 10 & 13.2 \\
$40-49$ & 5 & 6.6 \\
50 and Above & 2 & 2.6 \\
Level of Education & & \\
No formal education & 1 & 1.3 \\
Primary Education & 3 & 3.9 \\
Secondary Education & 48 & 63.2 \\
Tertiary Education & 24 & 31.6 \\
Gender & & \\
Male & 23 & 30.3 \\
Female & 53 & 69.7 \\
Household Size & & \\
$<5$ & 37 & 48.7 \\
6-10 & 32 & 42.1 \\
$11-15$ & 7 & 9.2 \\
\hline
\end{tabular}

Source: Field Survey, 2016.

Table 2. Preferred Groundnut Type by Respondents.

\begin{tabular}{lll}
\hline Preferred & Frequency & Percentage \\
\hline Boiled & 27 & 35.5 \\
Roasted & 7 & 9.2 \\
Fried and tied in polythene & 13 & 17.1 \\
Fried and bottled & 29 & 38.2 \\
Total & 76 & 100 \\
\hline
\end{tabular}

Source: Field survey, 2016.

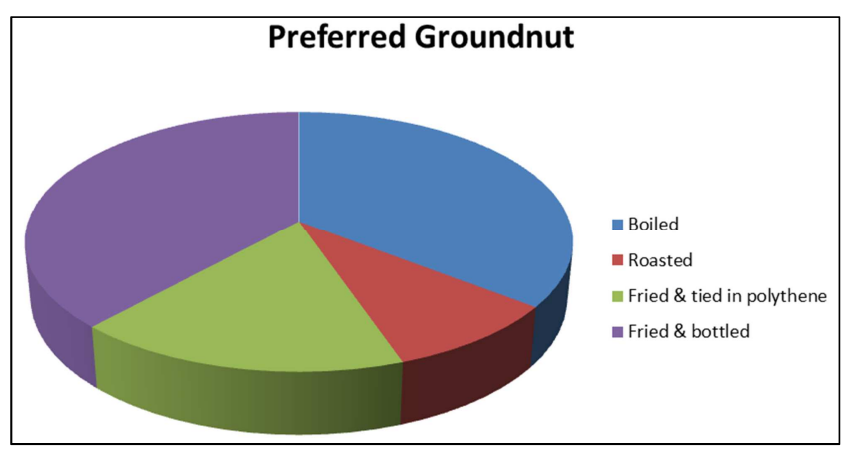

Figure 1. Pie Chart of Preferred Groundnut Type by Respondents.
Table 3. Factors Influencing the Groundnut type Preferred by the Respondents.

\begin{tabular}{lll}
\hline Factors & Mean & Remark \\
\hline Taste of groundnut & $2.91^{*}$ & Important \\
Ability to store for long & $2.53^{*}$ & Important \\
Price & $2.30^{*}$ & Important \\
Quality/size of groundnut & $2.24^{*}$ & Important \\
Bottle & $2.11^{*}$ & Important \\
Distance to point of sale & 1.84 & Not important \\
Use of polythene & 1.75 & Not important \\
\hline
\end{tabular}

Source: Field Survey, 2016.

*Important (mean $>2.00)$.

Table 4. Forms of Groundnut Frequently Consumed by Respondents.

\begin{tabular}{lll}
\hline Form & Mean & Remark \\
\hline Fried and bottled & 3.28 & Frequent \\
Fried and peeled & 2.92 & Frequent \\
Boiled & 2.83 & Frequent \\
Fried and placed in polythene & 2.39 & Not frequent \\
Roasted & 2.28 & Not frequent \\
Groundnut pealet and ball & 2.07 & Not frequent \\
Fried and unpeeled & 2.03 & Not frequent \\
Baked & 1.89 & Not frequent \\
Coated baked & 1.62 & Not frequent \\
\hline
\end{tabular}

Source: Field Survey, 2016

*Frequent (mean>2.50)

Table 5. Value Additions in Groundnut.

\begin{tabular}{lll}
\hline Value-added & Frequency & Percentage \\
\hline Peeled and canned & 59 & 77.6 \\
Peeled and bottled & 51 & 67.1 \\
Boiled with the husk plus salt & 46 & 60.5 \\
Fried with the husk plus salt & 40 & 52.6 \\
Groundnut coated with flour & 35 & 40.1 \\
Groundnut spiced with pepper & 29 & 38.2 \\
Groundnut plus corn & 26 & 34.2 \\
\hline
\end{tabular}

Source: Field Survey, 2016

Table 6. Constraints to Respondents Preference.

\begin{tabular}{lll}
\hline Constraints & Mean & Remarks \\
\hline Inadequate capital & 2.93 & Serious \\
Storage problem & 2.81 & Serious \\
Health problem & 2.65 & Serious \\
High cost of transportation & 1.88 & Notserious \\
\hline
\end{tabular}

Source: Field Survey, 2016

Serious (mean $>2.00)$

\section{Discussion}

Table 1 shows the socio-economic characteristics of the respondents. The result reveal that majority $(67.1 \%)$ of the respondents were between 20-29 years old, $13.2 \%$ were between $30-39$ years old, $10.5 \%$ were less than 20 years old, $6.6 \%$ and $2.6 \%$ were between the age of $40-49$ and 50 years old and above respectively and the mean age was 27 years old. This shows that the consumers of value added groundnut were young and are likely to consume more groundnuts because it's always advisable that as one gets older, one should reduce the intake of oily food. The table also revealed that $98.7 \%$ of the respondent had formal 
education, while $1.3 \%$ had no formal education. This finding indicates that the level of education is quite high. Reasons for this could be that in the study area there is a university institution which encourages people to further their education; this reveals that the respondents in the area tend to have knowledge about the benefit of eating groundnut and how it functions in the body system. It equally revealed that majority $(69.7 \%)$ of the respondent were male while $30.3 \%$ were female and also shows that majority (48.7\%) had household size of 5 and below, $42.1 \%$ had household size of $6-10$ and $9.2 \%$ had $11-15$ person. The average household size was 6 . This suggests that respondents have a manageable family size and would not spend too much on groundnut consumption.

Figure 1 shows that majority $(38.2 \%)$ of the respondents preferred fried and bottled groundnut while $35.5 \%$ preferred cooked groundnut, $17.1 \%$ and $9.2 \%$ preferred fried and tied in polythene and roasted groundnut respectively. This implies that many of the respondents preferred fried and bottled groundnut because they consider this type to be more hygienic and easy to consume.

Based on the mean result (mean $>2.00)$, Table 3 showed that the factors considered to be important in terms of influencing the groundnut type were taste, ability to store for long, price of groundnut, quality of groundnut and bottled groundnut while distance to point of sale and the use of polythene were not considered important factors; since the mean were less than 2.00 and does not necessarily influence the groundnut type preferred by the respondents.

Table 4 shows the form of groundnut frequently consumed by the respondents. Based on the mean result of 2.5 , the findings revealed that three forms of groundnut were frequently consumed by the respondents. These are fried and bottled groundnut, fried and peeled groundnut and boiled groundnut. Other types which include the fried and placed in polythene, roasted form, groundnut pealet and ball, fried and unpeeled, baked and coated baked was less frequently consumed since their mean score were less than 2.50. The finding suggests the respondents frequently consume only few forms of groundnut. Reasons for this is that fried and bottled is handy and last longer while for the fried and placed in polythene can easily be punctured thereby having holes making it unpalatable. The fried and the peeled saves the stress of peeling before consumption and the boiled groundnut is soft and easier to chew than the other forms of groundnut.

Table 5 shows that $77.6 \%$ of the respondents preferred peeled and canned groundnut, $67.1 \%$ preferred peeled and bottled, $60.5 \%$ preferred boiled with the husk plus salt, $52.6 \%$ preferred fried with the husk plus salt, while $40.15,38.2 \%$ and $34.2 \%$ preferred groundnut coated with flour, groundnut spiced with pepper and groundnut plus corn respectively. This revealed that majority of the respondents preferred peeled groundnut because of the value addition and because it can last longer and it is sweet.

Table 6 revealed that the constraints for consumer preference for value added groundnut based on the mean bench mark of 2.00 includes inadequate capital, storage problem and health problem were considered serious by the respondents while high cost of transport to point of sales was not a serious constraints. Many of the respondents considered inadequate capital as a serious constraint due to inability to purchase the choice groundnut because of the price attached to the preferred groundnut while storage problem was equally considered as a serious challenge because the cooked groundnut cannot store for long. Health problem was another serious factor because of the oily nature of groundnut and oily food are known to cause pimples and also increase the level of cholesterol in the body. Elderly individuals are advised to reduce their intake of oil food.

\section{Conclusion}

The study revealed that majority of the respondents were female $(69.7 \%)$, between the age of 20-29 years old, had formal education $(98.7 \%)$ with household size of less than 5 members $(48.7 \%)$. Fried and bottled, fried and peeled, and boiled groundnut forms were frequently consumed by respondents. It can be established from the study that consumers prefer value added groundnut because of its ability to store for long and it can easily be bought at affordable price. It taste sweet and it is easy to consume and also saves time. For this reasons more consumers will been courage to purchase value added groundnut, thereby reducing hunger.

\section{Recommendations}

Based on the findings of this study, the following recommendations were made:

1. Groundnut marketers should been courage to sell groundnut variety that is very tasty

2. Marketers should be encouraged to bottle the groundnut they sell to avoid contamination,

3. The marketers should be encouraged to form cooperative society which in turn we assist them in sourcing capital for their business.

4. Modern storage facilities should be provided for groundnut marketers.

5. Groundnut should be fortified with vitamins to encourage increased patronage.

\section{References}

[1] Ibrahim, H.Y., Saingbe, N.D. and Ibrahim H. I. (2010). An Evaluation of Groundnut Processing by Women in Rural Area of North Central Nigeria. Journal of Agricultural Sciences (2) 1 .

[2] Mugisha, J, Ogwwal, R., Ekere, O.W. and Ekiyar, V. (2004). Adoption of IPM Groundnut Production Technologies in Eastern Uganda. African Crop Science Journal. 12(4):383-391.

[3] Yvonne, C. (2007). "Changes in the Phytochemical Composition and Profile of Raw, Boiled and Roasted Peanuts". Journal of Agricultural and Food Chemistry. 55:22. 
[4] International Labour Organization (ILO) (1990). Small Scale Oil Extraction from Groundnut and Copra. Prepared under the joint auspices of the International.

[5] Bucheyeki, T.L; Shenkalwa, M.E; Mapunda, T; Matata, W.L. (2010). The groundnut clientoriented research in Tabora, Tanzania. In: African Journal of Agricultural Research Vol.5(5),pp.356-362.

[6] Bucheyeki, T.L; Shenkalwa, M.E; Mapunda, T; Matata, W.L. (2008). On-farm evaluation of promising groundnut varieties for adaptation and adoption in Tanzania .Afrcan Journal of Agricultural Research Vol.3 (8), pp.531-536.

[7] Nwenda, F.F. (1985). Groundnut Breeding and Improvement Programs in Tanzania. Regional Groundnut Workshop for Southern Africa, Lilongwe, Malawi, 1985, pp.81-87.

[8] Kim, J.O. and Jin, B.H. (2001). Korean consumer's patronage of discount stores: Domestics multinational discount stored shoppers profile. Journal of Consumer Marketing. 18(3):236255 .
[9] Sulochana, B.N., Bhargavik., Yellamanda, T. and Bas M.S. (2000). Culinary Preparations with groundnut, Recipe book in English, Hindi, Tamil, Telugu and Gujatati.

[10] Echekwu, C.A. and Emeka, I. (2005). Groundnut endowing, the groundnut/rediscovery programme in Nigeria. Opahmission Abuja pp.18.

[11] Keller, K.L. (2001). Building customer-based brand equity. Marketing Management. Vol.10(2):14.(19).

[12] Schiffman, L.G. (2007) Consumer Behaviour. $9^{\text {th }}$ ed. New Jersey: Prentice Hall.

[13] Richardson, P. (1997). Are store brands perceived to be just another brand? Journal of Product and Brand Management. 6(6):388-404.

[14] National Population Commission (NPC) (2006). Population Census Bulleting. 